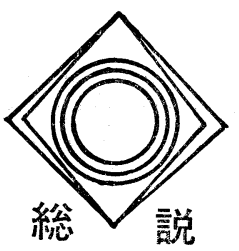

\section{都市ガス供給の展望}

-1980.9.24 受理一

\section{1. 都市ガス事業の概況}

都市ガス事業は，国民生活に不可欠なエネルギーを 安定して供給する責務を全うし，これをより普及させ ていく使命を担っている。

都市ガス事業者は全国に 249 社存在していることは 案外知られていないが，供給顧客数が 1,000 件にも満 た奴事業者から，約 600 万件の顧客を擁する事業者ま でまさに千差万別の事業者規模となっている。この 内, 大手事業者之いっているものは, 東京瓦斯, 大阪 瓦斯，そして，名古屋を主たる供給圈とする東邦瓦斯 であり，これら 3 社で，全国の顧客数の $70 \%$, 同ガス 販売量で $75 \%$ を占めて牧り，したがって，大手 3 社と それ以外の事業者の規模格差はきわめて大きいのが害 態である。

以下本項で济，こうした都市ガス事業者の原料状況 ガス需要用途の推移，現況などについて概括する。

まず都市ガス供給力の基盤となる原料状況について は，近年脱石油化がすすみ，表 1 飞示すと扣り，L N G，石炭などの非石油系のウェイトが全国で $63.5 \%$ (昭和54年度実績) 飞も達している。乞の内, L NG は42.9\%を占めて和り，昭和 44 年にアラスカから L N $\mathrm{G}$ 導入乙て以来, $\mathrm{L} \mathrm{NG}$ 比率は年々飛躍的飞増大乙 ている。しかしながら，LNGの導入にあたっては， 現地ガス田の開発，現地液化設備の建設， L N G 専用 タンカーの建造, および消費地におけるL NGターミ ナルの建設などに龙大な投資・費用を要することか ら，大手事業者以外の導入はほとんど不可能で西り， 上記の L N G 比率の増大はこれら大手事業者（実際に は, 東京, 大阪の 2 社) が担っている。したがって, 3 社以外の事業者は, ナフサ, L P G 亿原料を依存し ており，今後のガス供給の安定性には大いなる懸念が あるのが実情である。

昭和 54 年度の実績で, L NG 約 300 万 $\mathrm{t}$, 石炭 450 万

* 技術企画室

** 営業開発部 L N G 需要開発室 [東京都中央区八重洲1-2-16] $\mathrm{t}$ ，ナフサ180万kl，L P G120万t となっており，全 国ベースの一次エネルギー供給量との比較でみれば, きわめて小さいウェイトではあるが, 後述するよう に，近年は，産業用にガスが普及しつつあり， L NG の増大は今後とも続くものと考兄られる。

次にガスの需要用途について述べるならば, 表 2 に 示すように全国べースで全需要量の $82 \%$ 家庭用など の民生用途であり，工業用は，12\%を占めるにすぎ ず，民生用主体の需要構造に大きな変化はない。この ことが，ガス需要の夏期・冬期の大きな格差をもたら し，全体の設備稼動率を下げ，コストの回収に困難な 点を生ぜしめている。

次に設備投資の状況をみてみよう。都市ガス事業者 の投資分野はきわめて単純であり，ガス製造設備とガ ス供給設備の 2 つである。投資額の大半は供給設備で あり,これは, 年々増加する顧客に対応していくた め, パイプラインの新設, パイプラインの増強であ る。この傾向は, 今後も続くもの之考觉られる。

\section{2. 都市ガス供給力の展望}

都市ガスの供給力を決定する因子は，第一に原料， 第二に製造設備，第三に供給設備の能力である。

(1) 原料状況

冒頭に述べたように，大手事業者は，今後とも L N Gの導入を拡大していくが，L NGプロジェクトの性 格上，一定の大量需要を前提としなければならず，そ ら簡単に導入できるものでもない。現在 300 万 $\mathrm{t}$ 強の LNGを導入しているが，これは，アラスカ，ブルネ イ,インドネシア，アブダビからのものであり，今後 は，昭和58年にマレーシア（サラワク）から，60年頃 から，オーストラリア，ソビエト（十クーチャ）から の導入が考えられて拈り，その量も龙大であり，かつ いずれも 15-20 年の長期契約であることから， L NG を導入しらる大手事業者については，21世紀に至るま での原料入手については確たる見通しを得ているとい ってよい。（表 3 ）

一方，地方ガス事業者については，前述のとおり， 


\section{表 1 原料別・專業者別ガス送出量内訳}

(単位: 百万 $\mathrm{m}^{3}, 1$ 万 $\mathrm{kcal} / \mathrm{m}^{3}$ )

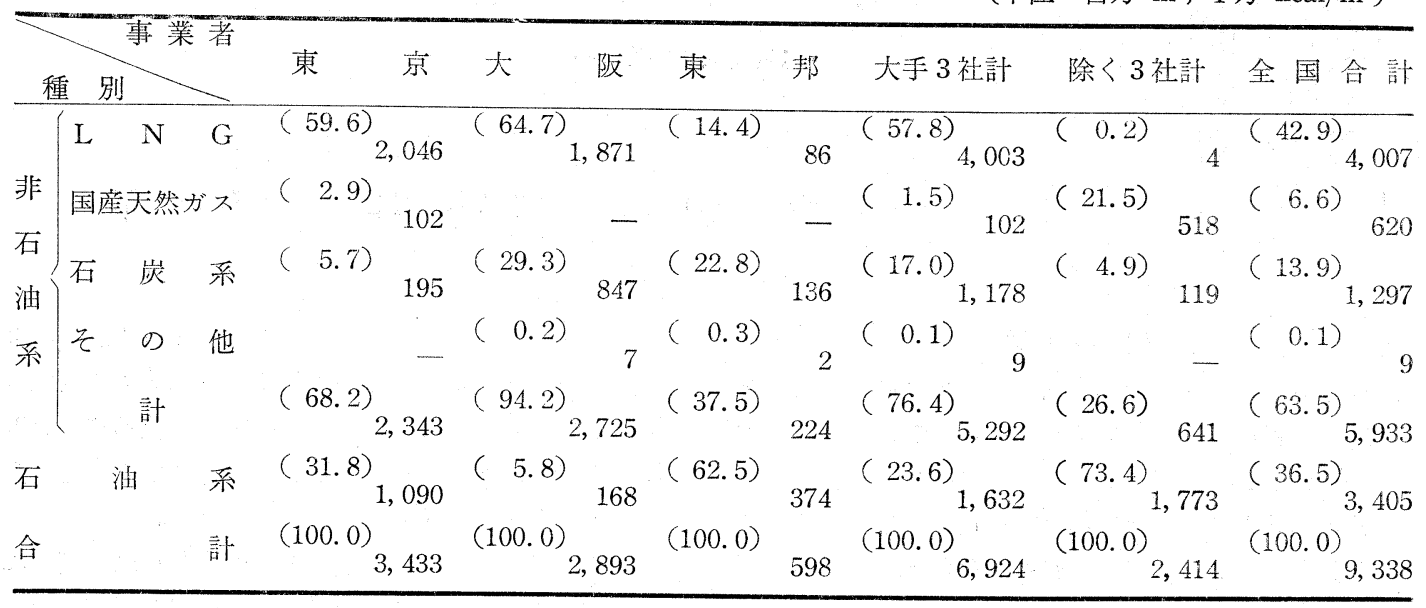

（注）上段（）内は構成比(\%)

（昭和54年度）

䨿 2 用途別ガス販売量の推移

(単位 : 百万 $\mathrm{m}^{3}, 1$ 万 $\mathrm{kcal} / \mathrm{m}^{3}$ )

\begin{tabular}{|c|c|c|c|c|c|c|c|c|c|c|}
\hline 年 & \multicolumn{2}{|l|}{50} & \multicolumn{2}{|l|}{51} & \multicolumn{2}{|l|}{52} & \multicolumn{2}{|l|}{53} & \multicolumn{2}{|l|}{54} \\
\hline $\begin{array}{l}\text { 用 } \\
\text { 途 } \\
\text { 別 }\end{array}$ & & $\begin{array}{l}\text { 構 } \\
\text { 盛 } \\
\text { 比 }\end{array}$ & & $\begin{array}{l}\text { 構 } \\
\text { 成 } \\
\text { 比 }\end{array}$ & & $\begin{array}{l}\text { 構 } \\
\text { 威 } \\
\text { 比 }\end{array}$ & & $\begin{array}{l}\text { 構 } \\
\text { 盛 } \\
\text { 比 }\end{array}$ & & $\begin{array}{l}\text { 構 } \\
\text { 盛 } \\
\text { 比 }\end{array}$ \\
\hline 家庭用 & $\begin{array}{r}4,543.6 \\
(104.7)\end{array}$ & 64.0 & $\begin{array}{r}4,991.8 \\
(109.9)\end{array}$ & 64.0 & $\begin{array}{r}4,965.1 \\
(99.5)\end{array}$ & 63.9 & $\begin{array}{r}5,179.8 \\
(104.3)\end{array}$ & 64.2 & $\begin{array}{r}5,447.3 \\
(105.2)\end{array}$ & 63.5 \\
\hline 商業用 & $\begin{array}{r}1,257.9 \\
(106.3)\end{array}$ & 17.7 & $\begin{array}{r}1,370.3 \\
(108.9)\end{array}$ & 17.6 & $\begin{array}{r}1,400.7 \\
(102.2)\end{array}$ & 18.0 & $\begin{array}{r}1,482.3 \\
(105.8)\end{array}$ & 18.4 & $\begin{array}{r}1,559.6 \\
(105.2)\end{array}$ & 18.2 \\
\hline 工業用 & $\begin{array}{c}891.9 \\
(107.1)\end{array}$ & 12.6 & $\begin{array}{c}980.7 \\
(110.0)\end{array}$ & 12.6 & $\begin{array}{r}937.4 \\
(95.6)\end{array}$ & 12.1 & $\begin{array}{r}905.6 \\
(96.6)\end{array}$ & 11.2 & $\begin{array}{r}1,048.8 \\
(115.8)\end{array}$ & 12.2 \\
\hline その他用 & $\begin{array}{c}403.1 \\
(110.1)\end{array}$ & 5.7 & $\begin{array}{c}449.9 \\
(111.6)\end{array}$ & 5.8 & $\begin{array}{c}464.7 \\
(103.3)\end{array}$ & 6.0 & $\begin{array}{c}502.1 \\
(108.0)\end{array}$ & 6.2 & $\begin{array}{c}525.7 \\
(104.7)\end{array}$ & 6.1 \\
\hline 計 & $\begin{array}{r}7,096.5 \\
(105.6)\end{array}$ & 100.0 & $\begin{array}{r}7,792.7 \\
(109.8)\end{array}$ & 100.0 & $\begin{array}{r}7,767.9 \\
(99.7)\end{array}$ & 100.0 & $\begin{array}{r}8,069.8 \\
(103.9)\end{array}$ & 100.0 & $\begin{array}{r}8,581.4 \\
(106.3)\end{array}$ & 100.0 \\
\hline
\end{tabular}

（注）（）内は対前年度比 
表 3 わが国の LNG プロジェクト

（1）実施中のプロジェクト

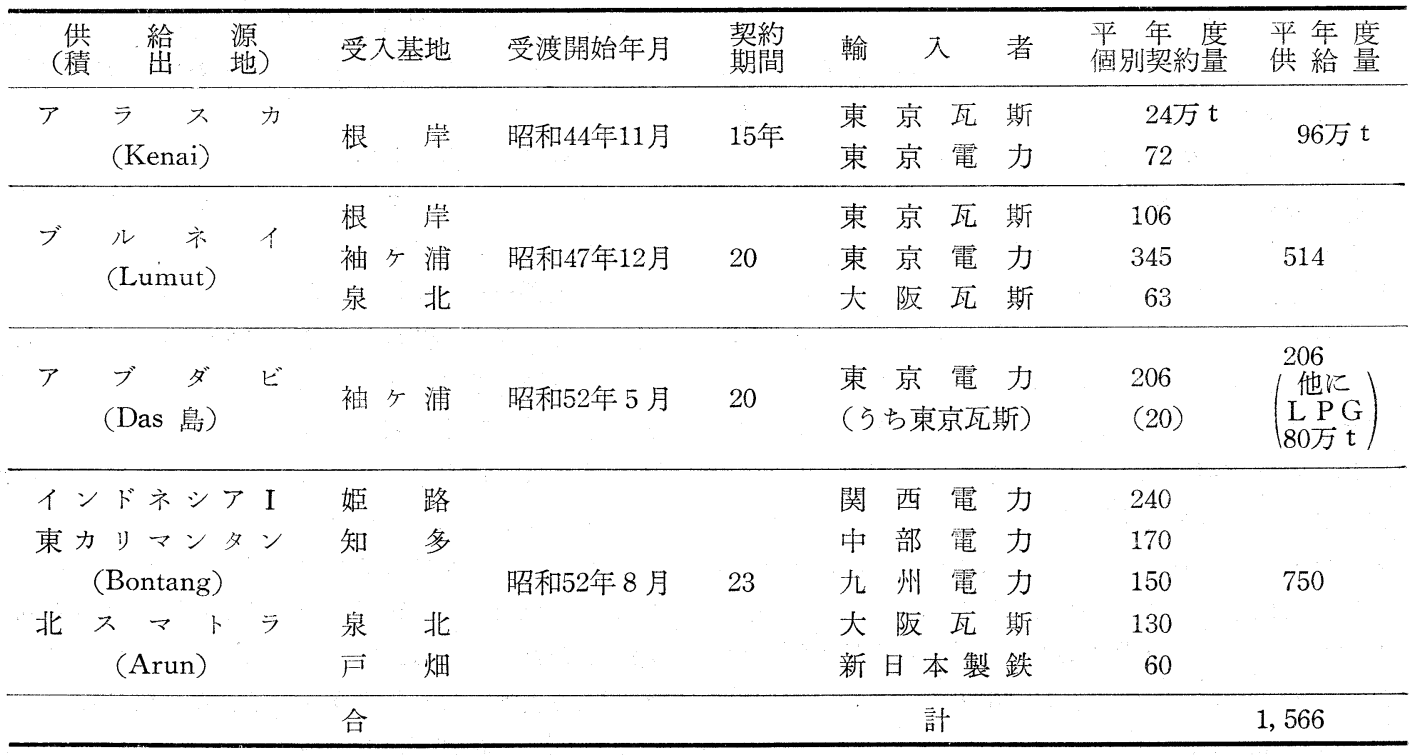

(2) 計画中・検討中のプロジェクト

\begin{tabular}{|c|c|c|c|c|c|c|}
\hline $\begin{array}{lll}\text { (供 } & \text { 給 } & \text { 源 } \\
\text { (積 } & \text { 出 } & \text { 港) } \\
\end{array}$ & 受入基地 & 受渡開始年月 & $\begin{array}{l}\text { 契約 } \\
\text { 期間 } \\
\end{array}$ & 輸 入 者 & $\begin{array}{l}\text { 平 年 度 } \\
\text { 個別契約量 }\end{array}$ & $\begin{array}{l}\text { 平年度 } \\
\text { 供 給 量 }\end{array}$ \\
\hline $\begin{array}{c}\text { マレーシアサラワク } \\
\text { (Bintulu) }\end{array}$ & 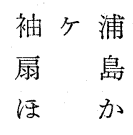 & 昭和 58 年 1 月 & 20 年 & $\begin{array}{l}\text { 東 京 瓦 斯 } \\
\text { 東 京 電 力 }\end{array}$ & $\begin{array}{l}200 \text { 万 } t \\
400\end{array}$ & 600 万 t \\
\hline $\begin{array}{c}\text { オーストラリア } \\
\text { (Withnell Bay) }\end{array}$ & - & 昭和 61 年 4 月 & 14 & $\begin{array}{l}\text { 電 力, ガ } \\
\text { 各 } \\
\text { 社 }\end{array}$ & - & 600 \\
\hline $\begin{array}{c}\text { イ ドネシア II } \\
\text { (Bontang) }\end{array}$ & $\begin{array}{l}\text { 姫 路 } \\
\text { 知 多 } \\
\text { 泉 北 }\end{array}$ & 昭和58年 & 20 & $\begin{array}{cccc}\text { 中 } & \text { 部 } & \text { 電 } & \text { 力 } \\
\text { 関 } & \text { 西 } & \text { 電 } & \text { 力 } \\
\text { 東 } & \text { 邦 } & \text { 瓦 } & \text { 斯 } \\
\text { 大 } & \text { 阪 } & \text { 瓦 } & \text { 斯 }\end{array}$ & $\begin{array}{r}150 \\
80 \\
50 \\
40\end{array}$ & 320 \\
\hline $\begin{array}{cccc}\text { イ } & \text { フ } & \text { ン } \\
\text { カ } & \text { ガ ン } & \text { 沖 } \\
& \text { (Kangan) } & \end{array}$ & 新潟東港 & - & 20 & $\begin{array}{l}\text { 東北電 力 } \\
\text { 新潟共同火力 } \\
\text { 石油資源開発 } \\
\text { 協和ガ ス化学 } \\
\text { 北陸 瓦 斯 } \\
\text { 三菱ガ ス化学 }\end{array}$ & - & 260 \\
\hline $\begin{array}{c}\text { インドネシア III } \\
\text { (Lhokseumawe) }\end{array}$ & $\begin{array}{l}\text { 新潟東港 } \\
\text { ほ } \quad \text { か }\end{array}$ & 昭和58年 & - & $\begin{array}{l}\text { 東 京 電 力 } \\
\text { 東 北 電 力 }\end{array}$ & - & $150 \sim 300$ \\
\hline $\begin{array}{c}\text { ソ連ヤクーチヤ } \\
(\mathrm{Ol} \text { ' ga) }\end{array}$ & - & $\begin{array}{l}\text { 昭和 } 60 \text { 年 } \\
\text { 以降の見达み }\end{array}$ & 25 & - & $\div$ & 750 \\
\hline 力 夕 - & - & $\begin{array}{l}\text { 昭和63年 } \\
\text { 以降の見込み }\end{array}$ & 20 & - & - & $\begin{array}{l}600 \\
\text { (見込み) }\end{array}$ \\
\hline 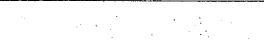 & 合 & & & 計 & & $80 \sim 3,430$ \\
\hline
\end{tabular}


今後ともナフサ，L P Gなどに依存せざるを得ず，今 後の供給力には舆念もあるが, 大手事業者の幹線に近 く立地する事業者については, 幹線からの卸しを受 け, L NGを主体とする大手事業者の長期安定的なガ スを受け入れることも可能であり, 極力, その方向を 目指し, 原料の安定確保を図ることが肝要であろう。

（2）製造能力状況

原料の L NG化を図るといらことは，製造設備とし ては， $-162^{\circ} \mathrm{C}$ の $\mathrm{NG}$ 海水を使って気化させるべ 一パライザーの設備増強を意味するが，金額的にも用 地的にもよりウェイトが高いのは, L NGタンクの建 設である。すなわち, 前述したように, ガス需要の季 節格差を年間一定で供給される L N Gで対応するため にはある程度の季節調整用としての L NGタンクが必 要となるわ忛である。大手事業者については, 既存の L NG 基地の増強によって, これらべーパライザー, L NG タンクとも建設可能であり, 原料供給に対応す る製造能力は万全といらことが出来る。

(3) 供給体制

供給体制については，各社まちまちであり，一概に 評価することはできないが，大手事業者については， L NGの高カロリー化化対応し, しか子効率的輸送体 制の確立を目指して, 高圧の天然ガス環状幹線を建設 している。したがって, 幹線さ兄確立されていれば, 需要増加には, 中圧パイプラインの敷設で対応するこ とが出来得る体制となる。例えば, 東京瓦斯の場合で は, 今後 $4 \% /$ 年率で需要量が増加しても, わずかの 中圧ラインの建設によって, 2,000 年近くまでの需要 量の増加比対応できる見込反である。

\section{3. 都市ガス需要の展望}

以上, 都市ガスの供給力について原料, 製造, 輸送 の各面が将来的㳊保されることを述べたが, 次 にこれからの課題である需要の展望について述べょ ら。

（1）民生用需要の展望

民生用ガス需要量は, 瞟和48年までGN P あるいは 個人消費支出の伸びと対応して，増加してきたが，第 一次石油危機以降, その傾向は消隇した。すなわち, 電気料金と同様，ガス料金も上昇したため, 節約効果 が出てきたということもあるが，何よりも大きい要因 は, 家庭用のガス需要量, 具体的には, 暖房用, 欴房 用, そして給湯用の需要量の増加に一応のカべが生じ てきたといらことである。われわれの日常の生活を改 めてみるまでもなく, これ以上の器具の增加は期待し らるものではなく, したがって, 今後のガス販売量の
増加は, 既存の一件当りの増量ではなく, 新規の需要 家増によるガス増量によるものに限られてしまらこと になるが，住宅の増加も近年落ちつつあることを考光 れば，これとても飛躍的な增大は望めないのが一般的 な見方である。

(2) 産業用需要の展望

そこで，クローズアップされるのが，産業用熱源と しての都市ガスの普及である。

民生用需要が伸び悩むことが必至であることから， 都市ガス事業者が健全な企業発展を目指すためには, 産業用熱源需要の都市ガス化が必須の課題となる。こ れはまた，産業用需要が大量でしかも年間一定の規模 を有することから，製造設備，パイプラインの稼動率 を高めることに大きく貢献し、 コスト上昇の抑制とい ら面からも大きく期待される需要分野で女る。

先に見たと和り都市ガスの工業用のウェイトは $10 \%$ 強でしかないが，これを全体の $1 / 4$ 程度にまで拡大し ていこうとするのが都市ガス事業者の計画である。

ところで, 都市ガスの工業用熱源（ボイラ一，圧延 加熱炉，焼鈍炉，鏗造炉，溶解炉等々）としての優位 性は，油に比べ大いなるものはあるが，エネルギー価 格という点で都市ガスは高く, このため, 産業用熱源 としての都市ガスの普及はごく小さいものとなってい た。(表 4) しかし，国のエネルギー政策にまつまで もなく, L NGの導入, 拡大は, 代替エネルギーの導 入促進といら点で, 原子力と並んで柱となるものであ り，その点からは，LNGを主原料とする都市ガスの 普及拡大は，国全体の代替エネルギーの拡大につなが るものである。こうした点に鑑み，LNG(都市ガス) の導入を拡大するためには, 従来の高価格から, これ を引き下げ，他の油燃料と同程度にむですることが必 須の課題となり，昨年 3 月末，国の総合エネルギー調 查会都市熱エネルギー部会は，新たな L NG 料金制度 の新設を打ち出したのである。

本制度の適用条件は年間一定でしかも長期にわたっ て大量な需要であることであり, これによって, 比較 的低料金の水準が達成されるわけであり,すでに大阪 瓦斯では昨年の 9 月から, 東京瓦斯では本年の 5 月か ら制度を実施に移し，今日で雨社を合せて約 40 万 $\mathrm{t} の$ 産業用 LNG契約が実現している。

ここで, この産業用 L NG需要量の今後の展望をみ るならば, 当面の対象として，洒格がきわめて低いC 重油を除くものを考学れば, 関東地域で約 150 万 $\mathrm{t}$, 関西地域で 120 万 $\mathrm{t}$, 名古屋地区で 40 万 $\mathrm{t}$, 合計 300 万 $\mathrm{t}$ 強の需要が考兄られるところであり, 今後の石油需 
表 4 産業用における都市ガス利用例 (日本) [業種別]

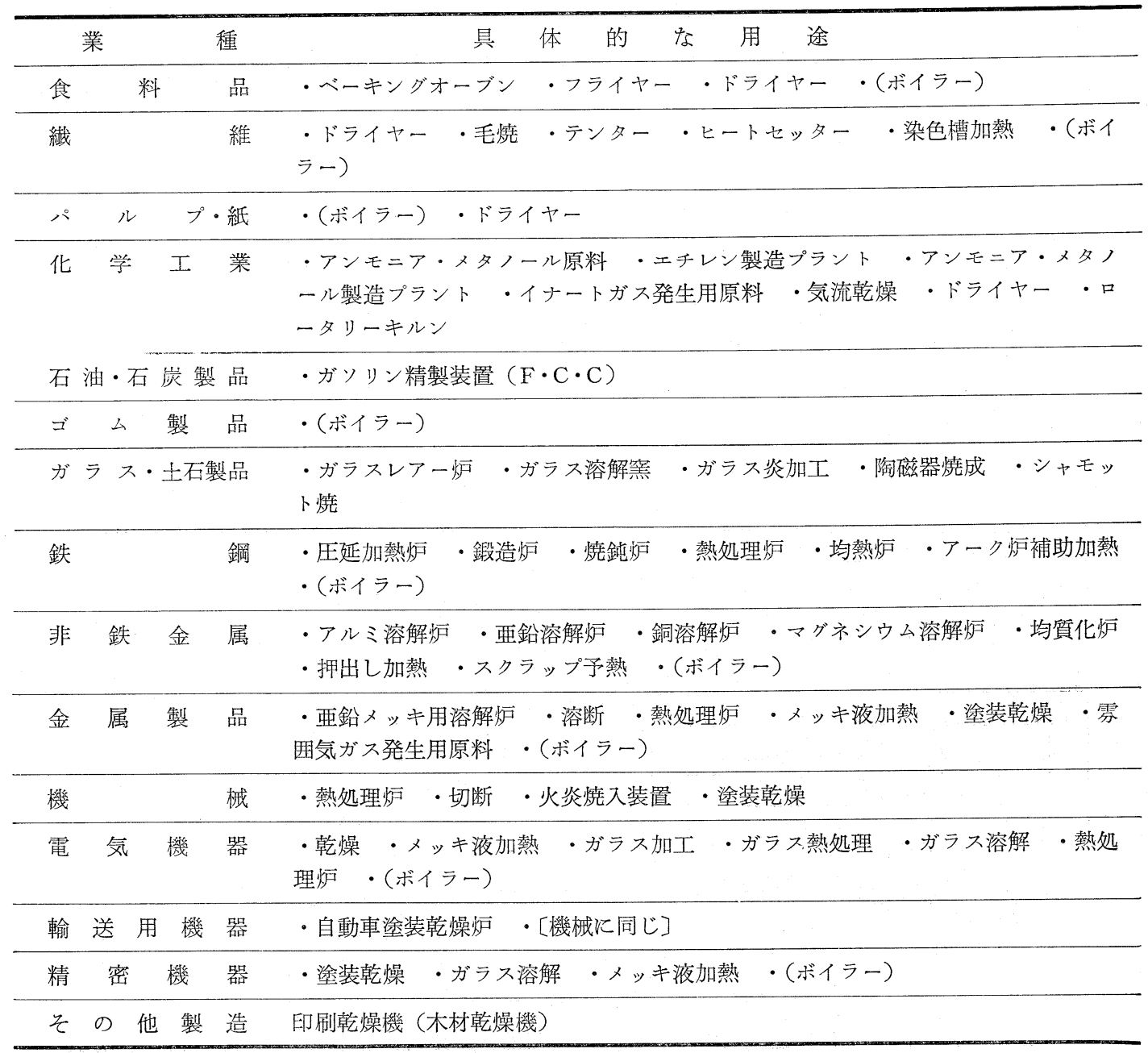

（注）ボイラーは各業種にまたがって利用されている。

給の動向ならびに石油製品価格の動向如何によっては この量はさらに抎大しらるものと考えてよい。

したがって，今後の都市ガス需要の展開としては, 今後伸びが期待されない家庭用をはじめとする民生需 要に代って, 産業用L NGが増大し, そのウェイトも 高まり, 都市ガス事業創業以来の不変の需要構造がこ の10～15年で大きく変貌することになりそらである。

将来的には，現在わが国L NGの 8 割方を消費して いる電力用途が原子力の開発拡大に伴なって減少し, 一方これからますます増大するL NG輸入量を, 都市 ガス事業者が産業用熱源として都市ガスを普及させる ことによって消化していくパターンが現実化するであ ろうし，またそうでなければならないといらことで
ある。

また, 都市ガス需要の将来の方向としては, 全く別 の角度から, 都市に蛙ける総合的なエネルギー需給シ ステムを形づくることによって，需要を拡大していく ことも夢ではなく，それが，次項に述べる，燃料電 池，ならびにコミュニティ・エネルギー・システム（C E S）である。

\section{4. 都市ガスにおける新しいエネルギー供給シス テムの展望}

国民生活の向上を豊かな地域社会の建設によって果 しつつ，そのためのエネルギー需給システムを，資源 およびェネルギーの有効利用の観点から構築して行く ことが, 現在重要な課題となりつつあり, 都市ガス事 


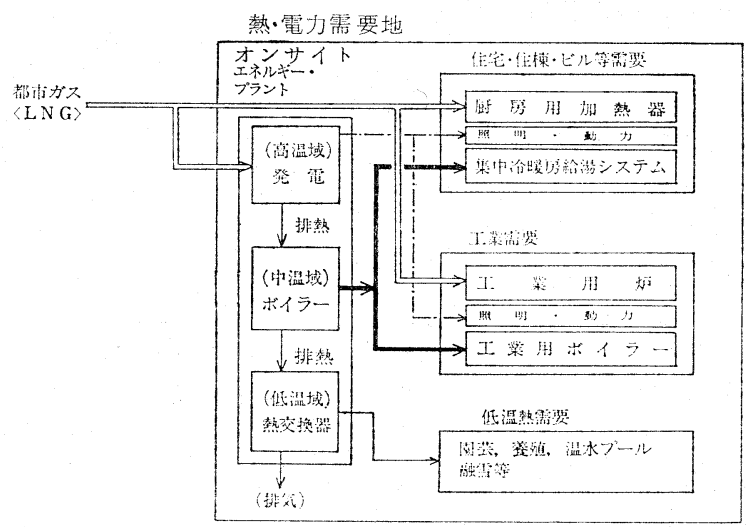

图 1 都市ガスによる新しいエネルギー供給システム

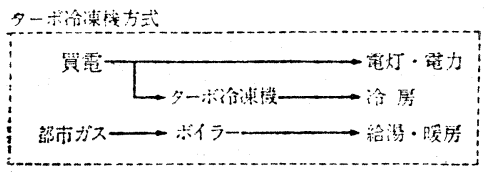

(a) 啀存システム

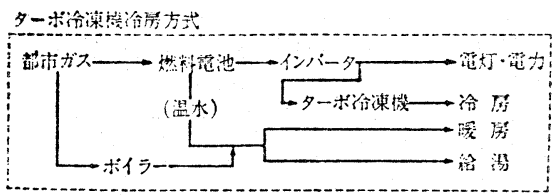

(b) 地相池システム

図 2 代表的な既存システムと燃料電池トータル エネルギーシステム

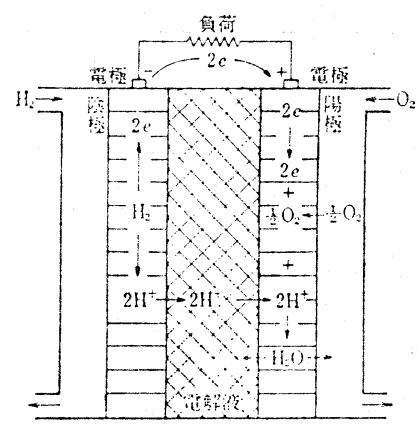

图 3 燃料電池の原理

業のより幅広い役割が期待されている。

このような必要性に対して, 都市ガス事業はこれま でも，地域社会や消費者の多様な要望に応えてきた が，今後は，都市ガス利用の概念をさらに拡げて，同 じ都市エネルギー供給者である電力事業と協調するこ とによって，新たなエネルギー供給システムを検討，
導入して行くことが重要である。

ここで述べる「然料電池トータルエネルギーシステ ム」和よび「コミュニティ・エネルギー・システム」 (Community Energy System=CES) は, このよう な都市ガス利用の新たな概念をまとめたものである。 これは図 1 に示すように従来の地域冷䁔房やビル集中 冷暖房の概念をさらに発展させて, 都市ガスを燃料と した然料電池あるいはガスタービン・スチームタービ ン複合サイクルの発電システムを組达名，個別建物や 地域レベルでのトータル・エネルギー・システムを実 現するるのである。すなお口，オンサイトで必要な電 力特よび熱エネルギーをその規模や質にマッチさせ て，高效率で供給しよらとするシステムである。この システムは, 都市ガスのエネルギーを付加価值の高い 電力に変換し, 照明・動力に利用するとともに, その 排熱を蒸気や温水に変换して冷暖房需要や温水プール などの低温熱需要に利用することによって, 省エネル ギー，省資源を達成しようといらものである。

4.1 然料電池トータルエネルギーシステム1),2)

然料電池トータルエホルギーシステムは，良来のエ ネルギー供給システムとは異なって，図2に示すよう に，都市ガスを燃料とした然料電殸発電システムを， ビル等の建物に設置しこれによって発電すると同時 に，その排熱を回収して泠䁔票・給湯を行い単一エネ ルギーで建物全体のエネルギーを賄い, 省エネルギー を図るものである。

ここで述べる燃料電池は, 環境面, 省エネルギー面 で在来の発電方式には類をみない性能を有し, 次代の 電気エネルギー変換機として最近特に注目されている ものでめる。在来発電方式が, 化学エネルギー一熱エ ネルギーー機㭊エネルギーー電気エネルギーといった 


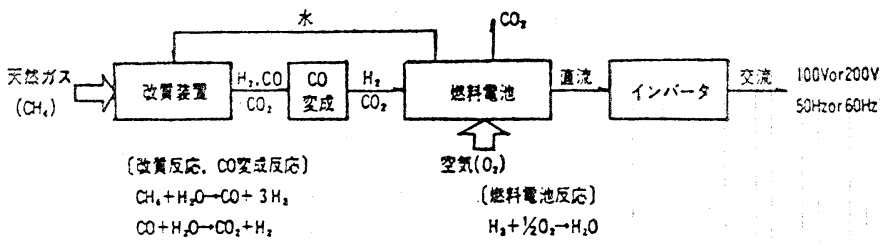

娄 4 天然ガス燃料電池フローチャート

変換過程を経るのに対し, 燃料電池は, 中間の変換過 程を省略し, 化学エネルギーー電気エネルギーと直接 電気を得る発電方式であり, 変換効率がきわめて高い ものである。

\subsection{1 燃料電池の原理}

燃料電池は外部から連続的に供給される燃料と酸化 剤（空気または酸素）との還元作用により電気エネル ギーを得る方式であり, 電池自身の持っている化学エ ネルギーを利用する一般の電池とは異なるもので岕 る。

然料電池は, 使用する燃料, 電解溶液の種類, 作動 温度によって，種々のものが考えられるが，この中で 最も実用化に近い水素・酸素然料電池について, その 作動原理を図 3 亿示す。

$$
\begin{array}{ll}
\text { すなわ方, 水索極 } & \mathrm{H}_{2} \rightarrow 2 \mathrm{H}^{+}+2 \mathrm{e} \\
\text { 酸素極 } & 1 / 2 \mathrm{O}_{2}+2 \mathrm{H}^{+}+2 \mathrm{e} \rightarrow \mathrm{H}_{2} \mathrm{O}
\end{array}
$$

となり, 電子の移動を直接電気として取り出す。また 全体として, $\mathrm{H}_{2}+1 / 2 \mathrm{O}_{2}=\mathrm{H}_{2} \mathrm{O}$ の反応が行われたこ とになり，この生成した水を適当な方法によって除去 すれば，電池自身はまったく变化を受けないことにな る。

\subsection{2 燃料電氾の開発状況}

1967年アメリカのガス会社を中心に「ガスエネルギ 一変換推進チーム」(Team to Advance Research for Gas Transformation=TARGET) を組織し，図 4 亿 示すような天然ガスを燃料とした燃料電溜の開発に着 手した。この組織に，東京瓦斯叔よび大阪瓦斯も参加 して拈り，実際の開発は，アポ口宇宙船等で実績を有 する United Technologies 社が担当し，1977年まで に, P C-11型燃料電池を開発し，実用化の目途を得 た。この P C - 11型燃料電池は, 電気出力 $12.5 \mathrm{~kW} て ゙$ あり，64基を製作し，1970年から1972年の間にフィー ルドテネトを行い計20万時間の運転実績を得た。東京 瓦斯和よび大阪瓦斯においてもこのテストを行い，多 大の成果を収めた。

この燃料電池は, 電解溶液をりん酸とした低温タイ プの水素・酸素型のものであり，水素源は天然ガスの

\begin{tabular}{|c|c|}
\hline 空挌出力 & $40 \mathrm{~kW}(7 \mathrm{jt} ; 85 \%)$ \\
\hline 発霄勃洪 & 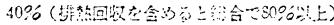 \\
\hline 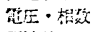 & 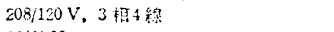 \\
\hline 䖝楛数 & $50 / 60 \mathrm{~Hz}$ \\
\hline 开 争 & 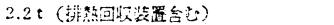 \\
\hline 寸洼 & 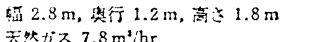 \\
\hline 授作 & 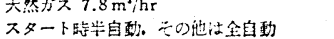 \\
\hline 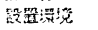 & 居外。是的 \\
\hline
\end{tabular}

表 5 PC-18 仕様

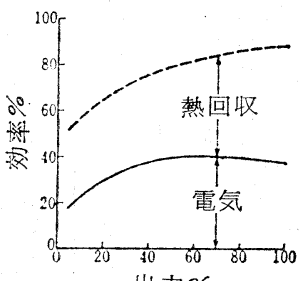

出力 $\%$

图 5 燃料電池性能曲線

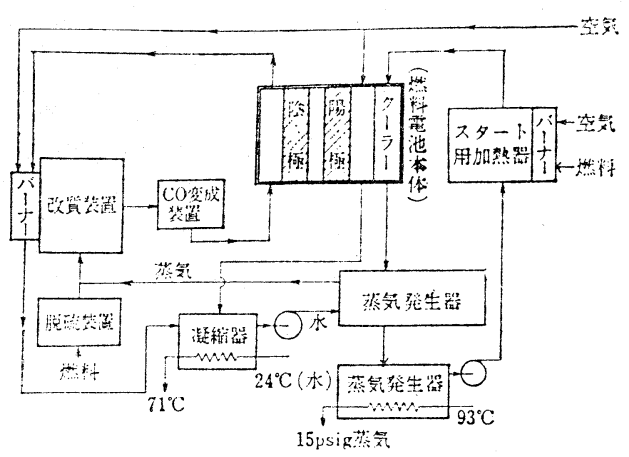

図 6 燃料電池排熱回収システム

改質により，酸素源には空気を使用している。また総 合熱効率を高めるために，電池反応の際に生ずる熱を 温水または蒸気として回収するシステム（排熱回収装 置) が組込まれて拈り，オンサイトに和ける熱供給も 可能である。

これに引き続き，商品化を目禋としたP C - 18 型然 料電池の開発に着手し, 現在, フィールドテストが可 能な段階に至っている。1978年からは，開発組織が前 述のターゲットから Gas Research Institute (GRI) に移管され，必要資金も民間資金ベースから政府資金 


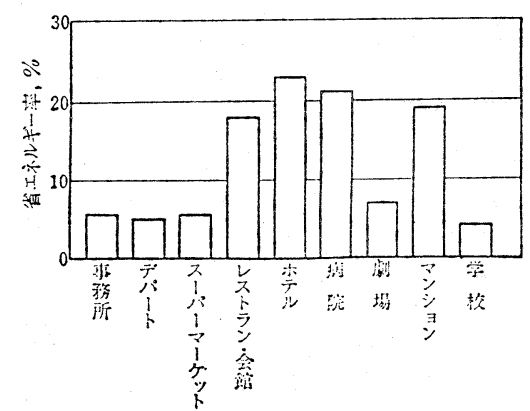

図 7 業種別省エネルギー率

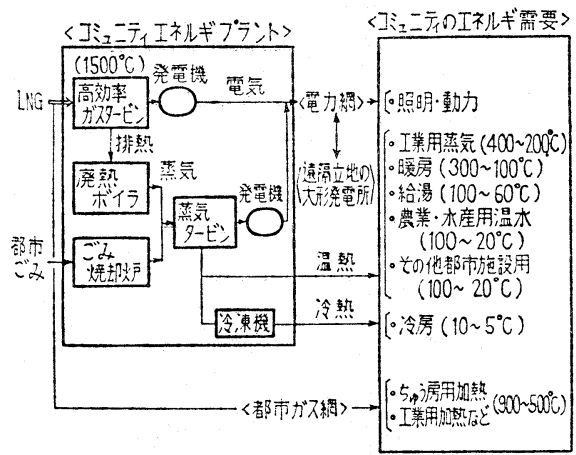

図 8 コミュニティエネルギーシステムの概念図

ベースに移り，具体的な商品化計画が進行中である。 今後のスケジュールとしては，1982１983年にかけ て，フィールドテストを行い，1985年以降市場導入の 予定である。商品化機種 P C-18 の仕様と性能を表 5, 図 5 に，排熱回収システムの例を図6に示す。

一方, 電力事業にあっても, メガワット級の然料電池 の開発が,アメリカで進められて和り, 1972年F C G-1 計画として発足し， $1,000 \mathrm{~kW}$ のパイロットプラント の実証試験を経て，4,800kW のデモンストレーショ ンプラントをニューヨークのコンソリテーテッド・エ ジソン電力会社が設置して，来年初から試運転に入る 予定である。また，東京電力に执いても，同種の燃料 電池発電所を現在建設中であり，1982年から試運転に 入る予定である。

\subsection{3 燃料電池の特徴}

燃料電池は, 他の発電方式に比べて, 次のような多 くの特長を持っている。

(1) 效率が高い。

全負荷時および部分負荷時の効率がきわめて高く, 特に部分負荷時の効率が良いことは, 年間, 月間の激 しい負荷変動に対して, 高效率運転が可能となり, 省 エネルギーに寄与する。また，小出力規模のものでも
高効率であり, 特に, GR I で開発している P C-18は, 排熱回収による温水・蒸気の利用が可能であり，その 総合熱効率は，80\%とすることができる。

(2) 環境問題が少ない。

ボイラーや回転部がないために, 大気污染排出物が 少なく, 騷音・振動が核とんどない。また, 冷却方式 が空冷も可能であるため特別な取水・排水の対策が不 要であり, 立地問題の解決に大きく貢献する。

(3) 効率的な設備投資が可能である。

燃料電池は，モジュール構造となっているため，容 易に発電出力の規模に合わせることができる。このモ ジュールは, 大部分を工場で組立て, トレーラーで現 地に輸送することができるため，建設が容易である。 また，建設期間も， F C G-1クラスの然料電池でも約 2 年と短かく, 乙か子増設が容易なため, 需要に対応 した効率的な設備投資が可能である。

\subsection{4 燃料電池トータルエネルギーシステムの 社会的意義}

然料電池は，以上述べたような特徽を有することか ら, 将来の電気エネルギー変換機の中で有望視されて いるものであるが，その構造上の制約から大型化に限 界があり, 本来必要とされる電力需要のすべてを賄ら ことは不可能である。従って, 燃料電池は, その特徵 を最大限に活かし，40 kW 程度から 3 万 $\mathrm{kW}$ 程度の 発電システムとして, 需要近傍地点に設置して大型火 力や原子力発電の補間的な役割を果たしていくものと 思われる。

一方, 燃料としてのLNGは，代替エネルギーとし ての役割りを果すと同時に，そのトータルエネルギー システムは, 総合効率が高いことから, 省エネルギー に寄与する。図 7 に，小型の然料電池をビルなどに設 置してトータルェネルギーシステムを組んだ場合の省 エネルギー率を示す。これは，図2に示すよらなシス テムで，一次エネルギーの省エネルギー量から算出し た值である。ホテル，病院，レストランは，省エネル ギー率が高いが，これは，燃料電池の排熱が有効に利 用される業種とみることができる。その他の建物につ いても，注ぼ $5 \%$ 以上の省エネルギーが図られてお り, 燃料電池トータルエネルギーシステムの開発導入 の社会的意義はきわめて高いといえよう。
4.2 コミュティ・エネルギー・システム $(\mathrm{C} \mathrm{E} \mathrm{S})^{3) \sim 8)}$

C E S は, 図 8 に示すように, 高效率ガスタービン を母体とし，これに蒸気タービンを複合させた発電シ ステムを電力・熱需要地に設置し，LNGを燃料とし 

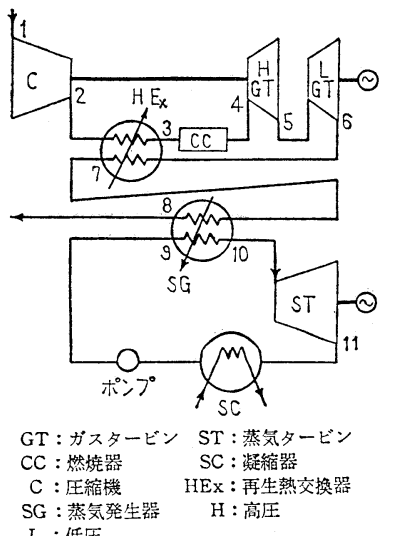

(a) システム構成

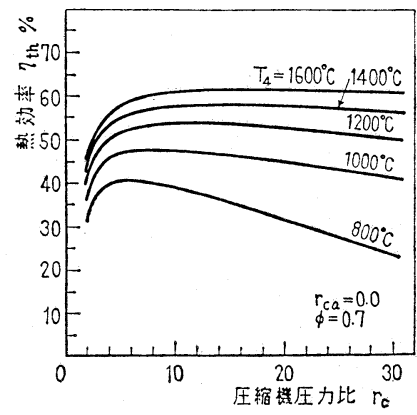

(b) ガスタービン入口温度と熱效革

図 9 開放再生サイクルガスタービン十蒸気ター ビンの複合サイクル機関

て高効率発電を行うとともに，排熱を地域への集中暖 冷房, 給湯に利用するほか, 地域社会で発生する都市 ごみなどの廃熱を有効に利用することによって，地域 全体の省エネルギー, 省資源を達成するシステムであ る。

ここで述ベるガスタービン・蒸気タービン複合発電 システムは, 高温から低温に至るまで熱をカスケード 的に利用することから，従来のシステムに比べて，そ の熱効率は, 現在に特いても高く, また将来飛躍的に 向上させることが可能であり，わが国において技術開 発が積極的に進められているものである。

\subsection{1 複合発電サイクルの熱効率}

最新鋭の大型火力発電所の蒸気タービン発電の熱効 率は，現在 $40 \%$ 程度であるが，これを図 9 に示すよう な開放再生サイクルガスタービン十蒸気タービンの複 合サイクル機関で考学ると，ガスタービン入口温度が 1, 500度の時, 約 $55 \%$ の熱効率となり, また 1,600 度の 時, 約 $60 \%$ の熱効率となることが期待される。

現在, 産業用のガスタービンでは, 入口温度は 1,100

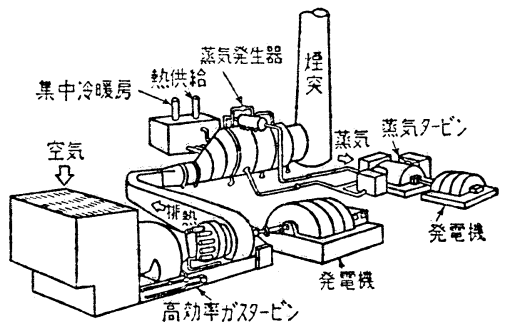

(出所) 工業技術院資料

図 10 「ムーンライト計画」における高効率複合 サイクル機関の概観

${ }^{\circ} \mathrm{C}$ 程度に達して和り, また, 航空機転用型ガスタービ ンでは， $1,200^{\circ} \mathrm{C}$ 程度に達し，その熱効率も飛躍的に 向上している。さらにまた，昭和53年度からスタート した通主省工業技術院の「ムーンライト計画」では, 図10に示すような高效率複合サイクル機関の開発が取 り上げられ，昭和 59 年度までの 7 年間にタービン入口 温度 $1,500^{\circ} \mathrm{C}$, 熱効率 $50 \%$ 以上の複合サイクル機関を 開発することをめざしている。

\subsubsection{E Sのもつ社会的意義}

新たなエネルギー需給構造に直面するわが国に扣い て, エネルギー源の多様化と資源の有效利用をめざ し，国民の福祉向上をはかるC E Sを実現すること は，国民経済あるいは土ネルギーの国際協調の観点か らも非常に有意義であることから，わが国に和いて は，1975年からこのような認識を共通に持つ学界やエ ネルギー関連産業界の有識者の間で, C E S 研究会 〔座長 $=$ 平田 賢東大工学部教授, (財)省エネルギー センターに設置〕を組織して調査研究を行っている。

高熱効率の “高温” ガスタービン十蒸気タービン複 合機関は, ガスタービンの出力からみて, 電気出力 2 万〜 20 万 $\mathrm{kW}$ 級の中・小型の発電所に適している。

すなわち，日本の必要全電力を本システムで賄らこ とは不可能であり，このシステムはベースロードをに なう大型火力や原子力発電所を補完するプラントとし て, 大都市の内部, 中・小都市の周辺, 団地队大型ビ ルなどの需要地の近傍に分散配置する“オンサイトプ ラント”として評価される。また, “高温・高効率”で あることから，C重油などの低質の燃料をたくよらな ことはせず, 脱石油, エネルギー供給源の多様化とい ら国のエネルギー政策に奇与し, 環境保全上も優れた クリーンェネルギーであるL NGを当面との然料とし て考觉る。

この複合サイクル発電プラントの大きな特徵は, $700 \sim 800^{\circ} \mathrm{C}$ と想定されるガスタービン排気をはじめ, 


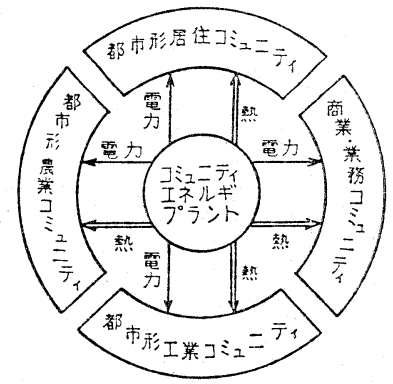

図 11 地域福祉型·省エネルギー型コミュニティ の構造

蒸気タービンの中間段から任意の温度条件の水蒸気, あるいは場合により種々の温度レベルの温水が利用で きることである。すなわち，複合サイクル発電プラン トはそのガスタービン排気をごみ処理の予熱めるいは 熱分解に用いて，ごみをボイラ一の補助燃料にすると か，蒸気や温水を工場用プロ七スめるいはコミュニテ ィ一の集中暖冷房, 給湯, 融雪に用いるなど, 地域熱 供給の中心プラントとして，きわめて利用しやすい形 をして和り，トータルエネルギーシステムの中核にな るプラントとして絶好の条件を備えている。

一方，新しいエネルギーシステムであるC E S は， 単なるハードウェアシステムで岁るぼかりでなく, 従 来, エネルギー供給が，単に地域づくりのための与件 として取扱われてきたのに対して，これは，より豊か な地域づくりのためのエネルギー供給システムとはな にかを積極的に考觉ることによって，新しい地域社会 そのものを構築するといった都市計画, 地域計画のソ フトの面まで関与するものである。すなわち，図11に 示すように, 都市を形成する各種コミュニティに効し て,コミュニティに必要な電力と熱を，その規模と質 に合わせて供給することによって, 都市エネルギー機 能 (電力とガス) とコミュニティ機能を合体させた地 域福祉型, 省エネルギー型コミュニティの構築を可能 にするものである。

このように，コミュニティの特性に応じて計画され たトータルエネルギーシステムは, 現状の大規模火力 発電所からの電力供給やオンサイトでのボイラーなど による熱供給による個別システムに比べ，図12に示す ように，ケースによっては，一次エネルギーに換算し た総合熱利用率を70～80\%と著しく高めることができ る。

また，このシステムによって地域との一体感が回復 され,「コミュニティ」のためのプラントといった感

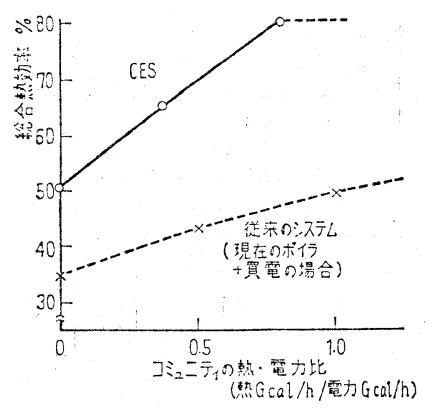

图 12 CES と従来のエネルギー供給システムの 濰合熱彸率 (一次エネルギー換算) の比較

覚で一般に受け入れられるよらになれば，付加的に発 電技術およびその社会的必要性が一般に理解され，現 在の電源開発の主体である大規模発電システムそのも のの社会的受容が容易になることも期待される。

\subsubsection{E S の省エネルギー性と今後の課題}

(財)省エネルギーセンターの下に設置されたCE S 研究会の「集合住宅に晾けるCES」に関する最近の 研究によると，入口温度 $1,500{ }^{\circ} \mathrm{C} ， 100 \mathrm{MW}$ 級ガスタ 一ビン複合サイクルを用いたC E S 括ける電力拈よ び熱の総合熱効率は，最大で $78.1 \%$, 年間平均で約 60 \%となり従来の土ネルギー供給システムに比べて, そ の熱利用は格段に高度なものになることが報告されて いる。

以上述べたように， C E S 研究会の研究している都 市型中小規模熱併給発電システムは，大規模火力発電 所, 原子力発電所を補完すると共に, 小型発電システ ムであるにもかかわらず，その熱效率が高いことか ら，エネルギーの有効利用が期待でき，その実現の意 義は大きい。

しかしながら，このシステムが「コミュニティ」の ためのプラントとして一般に受け入れられるために は, 社会心理学的, 環境的, 経济的, 制度的な側面か ら今後, 十分な研究が行われなければならない。

また，従来日本では電力・ガス・熱供給・ごみ処理 に関しては，事業主体が縦割りになって和り，それら 関連事業間の協調体制および法的な制約の解決を前提 としなければC E S の実現は困難である。

C E S 研究をきっかけとしてニネルギー供給産業 に地方自治体を加えた密接な協調体制が作り出される ならば，今後の最適なエネルギ一供給のあり方を検討 していく上で非常に有意義となろら。

\section{文献}

1）㐘地謙一，PETROTECH，1，第12号，19, 
(1978)

2）菊地謙一, 小倉正雄, 空気調和と冷谏, 10-1978

3）コミュニティ発電研究会, 高熱効率コミュニティ 発電システム調査研究報告畫(第 1 報), 昭52-6

4) コミュニティ発電システム研究会, 高熱效率コミ ュニティ発電システム調査研究報告書(第 2 報), 昭53-6

5) コミュニティエネルギーシステム研究会, コミュ
ニティエネルギーシステム調査研究報告畫（第 3 報)，昭54-6

6）平田 賢, 機械の研究，31-1，159，(1979）

7) 鴻栄 斌, 虎頭健四郎, 日本機械学会誌, 83-736, 253, (1980)

8）虎頭健四郎，茨木正章，日本瓦斯協会誌，32-8， 66, (1979)

\title{
Outlook on City Gas Industries
}

\author{
Kenshiro Koto, Shigero Kusano
}

(Tokyo Gas Co., Lid.)

SYNOPSIS: - It is the basic duty of the city gas industries as a utility industry to supply high-quality city gases stably and safely in answer to the permanent demand of their customers. At the same time, the industries are required to contribute to Japan's energy policy as one of the energy industries. It is an important goal of the energy policy to increase the portion of LNG-based energy as well as nuclear energy to Japan's total energy consumption. In this regard, the industries have been making a major contribution by using LNG as a key raw material, and on the other hand playing a significant role in the promotion of energy conservation in that thermal efficiency of city gas is extremely high.

The demand for gas has been growing in the residential and commercial markets and is expected to grow in the industrial sector. As to the future, industries play a major role to encourage the large-scale industrial usage of LNG-city gas.

Concentrated technical development work is being carried out in producing combined heat and power (electricity), which raises the overall system efficiency, lowers costs and makes city gas a more valued fuel, by using an on-site fuel cell and combined gas turbine-steam turbine system. 